Academic City University College - Accra Ghana

Society for Multidisciplinary \& Advanced Research Techniques (SMART) Africa

Tony Blair Institute for Global Change

FAIR Forward - Artificial Intelligence for All - Deutsche Gesellschaft für Internationale Zusammenarbeit (GIZ) GmbH

Accra Bespoke Multidisciplinary Innovations Conference (ABMIC)

\& The Africa Al Stakeholders' Summit

14th December, 2021

\title{
Critical Analysis of Cloud Computing Adoption in East Africa
}

Isaac Odun-Ayo, Isaac Martins, Tomi Mohammed, Deborah Etukudo, Victoria Robert

Department of Computer and Information Sciences

Covenant University

Ota, Nigeria

Email

isaac.odun-ayo@covenantuniversity.edu.ng

Isaac Odun-Ayo, I.A., Martins, T.M, Etukudo, D. \& Robert, V. (2021): Critical Analysis Of Cloud Computing Adoption In East Africa. Proceedings of the Accra Bespoke Multidisciplinary Innovations Conference. University of Ghana/Academic City University College, Accra, Ghana. December 2021. Pp 25-46. www.isteams.net/ghanabespoke2021.

DOI https://doi.org/ 10.22624/AIMS/ABMIC2021P3
} 


\title{
Critical Analysis of Cloud Computing Adoption in East Africa
}

\author{
Isaac Odun-Ayo, Isaac Martins, Tomi Mohammed, Deborah Etukudo, Victoria Robert
}

\begin{abstract}
Abstract. Cloud computing is the practice of delivering on-demand computing resources such as servers, storage, databases, software, etc. This has created a paradigm shift in how things are being done by organizations regarding their IT operations. In some regions of East Africa, there is a decline in the level of Cloud computing. The study aims to provide an understanding of the status and trends for cloud computing in East Africa from several perspectives, including adoption, impact, and policy. The method utilized in the paper was a quantitative approach taken due to the existing literature reviews and case studies on cloud computing adoption in East Africa to provide detailed analysis so as not to limit the scope of the research for in-depth information. The result of this research describes how cloud computing is adopted in several East Africa countries and this will detail the current level of Cloud computing in the considered countries. Cloud computing was discovered to have been effectively adopted in the banking, marketing, education, and agriculture sectors as these sectors account for about $26 \%, 26 \%$, $25 \%, 23 \%$ respectively. With the Agricultural sector being relatively the least. Although Cloud computing is not rapidly and readily adopted in East Africa, the result above shows that there is a fair adoption of Cloud computing in these sectors listed in the outlined countries.
\end{abstract}

Keywords: Agriculture, Banking, Cloud Computing, East Africa, Education, Technology.

\section{INTRODUCTION}

The impressive growth of cloud computing in recent years has piqued the interest of Internet and IT users who want to get the most out of the services and applications available on the web in a service-on-demand mode with per-usage billing. Eastern Africa is mostly made up of plateaus and has the majority of the continent's highest elevations. Ethiopia and Kenya have the most striking highlands, with large areas reaching elevations of 6,500 to $10,000 \mathrm{ft}$. $(2,000$ to 3,000 meters). The East African Rift System runs through the region, with two parallel rift valleys. The Eastern or Great, Rift Valley extends southward from the Red Sea's confluence with the Gulf of Aden, through Ethiopia's and Kenya's highlands, and into Tanzania. The Western Rift Valley runs along Uganda's and Tanzania's western borders [1].

Depending on how ethnic groups are counted, Eastern Africa has 160 or more ethnic groups. The Cushitic branch of the Afro-Asian languages is spoken by the majority of people in Eritrea and Ethiopia, as well as those in Tanzania and Kenya. Cloud computing opens up a whole new world of possibilities. ICT economic model - a model that heralds new modes of IT investment and operation obtainable resources. With cloud computing, organizations, institutions, and businesses no longer need to invest heavily in such resources, which are by necessity limited and require time-consuming and expensive internal management, instead opting for a cloud model that allows them to buy or lease resources on the internet. The availability of online services also frees users from the need to acquire hardware by paying instead for the resources used. 
This model has already been adopted by many companies, particularly small and medium-sized firms and very small firms. Simply put, cloud computing is the delivery of computing services over the Internet ("the cloud") to provide faster innovation, more flexible resources, and economies of scale. You usually only pay for the cloud services you use, which helps you cut costs, run your infrastructure more effectively, and scale as your business grows [2].

There has been a definite shift around the discussion about the cloud in Africa. Businesses now accept the future of organizing, processing, and presenting their data is in the cloud, and with services like cloud-based email, many people are already using this innovative technology whether they know it or not. Organizations need to be able to adapt at the same speed as this new technology and take advantage of the opportunities it presents. This will ensure business continuity and resilience in the long term [3].

Cloud computing is set to become even more prominent, with companies able to automate and optimize more processes as connected smart machines are used. Interconnected systems mean that business processes and the actual equipment will be linked to ensure ease of access and optimization. This has the power to significantly improve efficiency for businesses that can get it right. This could include inventory systems that automatically order more stock when the levels are low; smart machines that notify you before a part needs to be replaced; or logistics tracking that optimizes routes and delivery based on orders and current traffic congestion. As we progress into the digital world of work, systems will become more interlinked and intertwined, providing opportunities for companies that are ready to take advantage.

While this may appear straightforward when discussing the various types of cloud computing available to individuals, it is a completely different "cloud" when it comes to businesses. The three services provided by cloud computing for enterprises are as follows: Platform as a Service (PaaS) clouds are designed by experts, often within laaS clouds (which we'll discuss further below), to provide scalability and distribution for any application while also assisting in the predictability of a company's costs. The main advantage of this service is that you can start developing your app without stress and at a very low cost. Because it is based on cloud computing, its construction allows for a lot of scalabilities. The only disadvantage of a PaaS cloud is that certain services may have limitations that will prevent your goods from working in certain situations.

Infrastructure as a service (laaS) allows businesses to access critical web infrastructures such as servers, connections, and storage space without having to purchase or handle it themselves. The managed service provider and the company that uses the infrastructure benefit from economies of scale and specialization. laaS, for example, enables an online business to evolve and grow quickly. Because the company that is delivering the software as a service is also maintaining the infrastructure to run the software in the first place, all PaaS and SaaS clouds are based on laas clouds. Your company will have to deal with the complexity if you choose an laaS cloud, but with that comes flexibility.

Software as a service (SaaS) is fairly mature, and its terms are similar to those found in cloud computing. Cloud applications make it possible to use the cloud as a software infrastructure. Because the application is run on computers owned by the vendor, the burden of support, maintenance, and operations are reduced. Cloud computing has been around for a while, but it will continue to develop as faster and more reliable networks provide greater benefits to both service providers and customers. 
There are more opportunities to create business models in an increasingly connected economy as a result of these advances. This study is to inform the decisions on adoption of cloud computing by prospective cloud services in East Africa, including possible significant benefits of its adoption to ensure informed and accountable information technology (IT) related decision making. The UN sub-region of East Africa consists of 20 states namely: Kenya, Tanzania, Uganda, Ethiopia, Rwanda, Somalia, Mozambique, Zambia, Burundi, Eritrea, Madagascar, South Sudan, Djibouti, Malawi, Seychelles, Mauritius, Zimbabwe, Comoros, Reunion Island, and Mayotte.

\section{RELATED WORK}

Cloud computing is the delivery of software and technology as services over the internet by service providers. According to the National Institute of Standards and Technology, it is a model for enabling ubiquitous, convenient, on-demand network access to a shared pool of configurable computing resources (e.g., networks, servers, storage, applications, and services) that can be rapidly provisioned and released with minimal management effort or service provider interaction [4]. In cloud computing, end-users do not require knowledge of the physical locations or configurations of the systems which provide relevant services to them.

It also has other key features like the elasticity of the amount of computing resources characteristics [5]. Industry analyst Gartner has predicted that by the time of this publication, the cloud market would have reached over $\$ 150.1$ billion and business processes delivered as cloud services will be significantly larger components of the overall cloud service market than application or infrastructure services [6].

Past studies have highlighted general performance challenges in Africa's Internet, including high latencies and generally poor quality of experience. A recent Performance barrier to cloud services in Africa 3 study by Formoso et al. (2018) showed that many parts of Africa still experience excessively high Internet delays, often exceeding $300 \mathrm{~ms}$. A study by Fanou et al. (2016) [7] also showed that Internet performance on the continent is largely characterized by slow download speeds and high delays.

Other studies have highlighted traffic engineering problems in Africa's Internet topology, showing a lack of direct interconnection amongst Africa's ISPs, resulting in a suboptimal performance for intra-country and cross-border communication, as well as a high cost of Internet access. Apart from the lack of direct network-level and country-level interconnections, other studies have looked at inefficient DNS configurations, as well as the lack of local content caching servers across the African continent.

\section{MATERIALS AND METHOD}

The purpose of this is to explain in detail the research methods and methodology implemented for this topic. The research methodology used in this research is grounded theory. Grounded theory is a well-known methodology employed in many research studies. Qualitative and quantitative data generation techniques can be used in a grounded theory study. Grounded theory sets out to discover or construct theory from data, systematically obtained and analyzed using comparative analysis. The first definition of grounded theory as put forward by the proponents of the method Glaser is "the discovery of theory from data". It is a qualitative approach that has been variously described as positivist, interpretive or critical. 


\section{Data Analysis}

Content analysis was used to analyze the data which was gathered from websites. Content analysis is a research method used to identify patterns in recorded communication. To conduct content analysis, you systematically collect data from a set of texts, which can be written, oral, or visual: books, newspapers, and magazines; speeches and interviews; web content and social media posts; photographs and films. Content analysis can be both quantitative (focused on counting and measuring) and qualitative (focused on interpreting and understanding) [7].

\subsection{Cloud Computing in Kenya}

Kenya is one of the fastest-growing tech-savvy ecosystems in East Africa. Kenya stands to be one of the most technological countries in Africa. On the four segments that Africa's patterns of notes, Kenya is known to be the country that paves the way, alongside South Africa. From a record in 2017, Kenya was said to be quickly advanced as a hot spot for some continent's most innovative digital enterprises. Over $75 \%$ of Kenyans aged from 15 years and above made mobile payments in the year 2016 [8].

\section{Agriculture}

With the development of technology and data, it has become very important in agricultural innovation systems. Technology has been put in place to aid agricultural activities. Cloud computing services have immense potential to improve agricultural innovation systems. The movement toward open access and public involvement through online or mobile tools also favors agricultural innovation, this is not just applicable to research institutions but also broadly applicable among all participants in an innovation system.

\section{Banking}

Cloud computing as relates to the banking industry in Kenya can offer several benefits for instance changing a large upfront capital expenditure to a smaller ongoing operational cost. Cloud computing majorly aids the conversion of capital expenditure (CAPEX) to Operating Expenditure (OPEX) because its resources are rather bought, therefore reducing the corporate opportunity cost of investment decisions in IT. The vendors of cloud services are utilizing a concept called utility Computing.

\section{Education}

In the evaluation of the current level of the various institutions from the perspective of the IT necessities, framework and projects cannot be transformed to be cloud-based applications or projects suddenly, this shifting must be step by step starting from experimenting with the CC techniques on the pilot application and then apply it on other chosen applications.

\section{Marketing}

In recent times, a lot of companies are changing their overall information and communication technology (ICT) strategies to embrace cloud computing to open business opportunities. The heaviest user of cloud applications are companies that manufacture hardware that enable cloud computing. The sector also contributes $30.60 \%$ of the GDP and accounts for $57 \%$ of the new job creation. 


\subsection{Cloud Computing in Rwanda}

Cloud computing is a service model where computing services that are available remotely allow users to access applications, data, and physical computation resources over a network, ondemand, or pay-per-use fashion.

\section{Agriculture}

Looking back over the last decade, IT has played a key role in the private sector's productivity improvements in industrialized countries by automating innumerable business processes, such as accounting, human resources, and customer relationship management (CRM). In turn, this automation has increased efficiency and triggered high growth in industries ranging from investment banking to farming, and revolutionized small and medium enterprises (SMEs), which makeup $90 \%$ of enterprises globally and account for $50-60 \%$ of all employment.

While many efforts to leverage ICT for the development of the private sector are taking place in Kenya, Tanzania, Senegal, Ghana, South Africa, Nigeria, and other countries in the region, one country is moving faster than others: Rwanda seems more aggressive than others in developing the right environment. Under the leadership of President Paul Kagame, whose ICT vision has been recognized by several international awards, the country has taken several critical initiatives. As a result, Rwanda was the number-one reformer worldwide in the World Bank's Doing Business 2010 Survey. In 2008-09 alone, Rwanda completed seven reforms to ease the path of investors doing business. An online business registration service has been officially launched in Rwanda, reducing the time it takes to register a company from a day to just one hour [9].

\section{Banking}

Digital transformation of the activities of financial services providers such as banks, microfinance institutions, and insurance companies is accelerating in Rwanda. Leading financial services providers, including major banks and insurers, recognize the significant benefits and competitive edge to be derived from cloud services, such as agility, scalability, cyber resilience, and secure access. As in many other countries, cloud services can help Rwanda to fully exploit the transformative power of information and communication technology by allowing a costeffective sharing of resources. Furthermore, cloud services can help reduce some of the challenges introduced by the significant capital expenditure required in information technology hardware infrastructure and software. In a highly regulated sector such as the financial services sector, it is however crucial to ensure that a move to the cloud ensures compliance with applicable regulation and achieves the intended benefits.

\section{Education}

Higher Educational Institutions hereinafter referred to as HEls, in Africa, and across the world are in the historic era. Information Technology (IT) aptitudes are alleged as significant cost centers, to many advocates, even though an institution relies on technology in every aspect of its operation, it is difficult to perfectly calculate the return-on-investment (ROI) from the cost of information technology. Correspondingly, it is challenging to attribute the benefits of technology in a straight line to the institution's vision, mission, and goals. Cloud computing is now a topic of significant impact and, while it may represent an evolution in technology terms, the truth behind this approach is that it has changed how both academia and industry are thinking and acting. 
If cloud computing is of today's key technologies for the modernization and realization of the public sector as advocated by many, the belief is that cloud is part of the new trend of technology that is set to take the computing experience to another level With huge finances needed in higher education globally and the growing demand for IT services, universities in Africa are facing challenges in providing essential Information and Communication Technology (ICT) support for educational, research and developmental activities. Although universities have been using "cloud-based" applications for years (e.g., email), the cloud computing fashion is quickly evolving into a premium model for data storage and exchange.

According to Gartner a technology research company, more than 50 percent of Global 1000 companies are predicted to store confidential data in the public cloud by the end of 2016 . The cloud is proving itself as being (a) tech-oriented that is here to stay. This is mainly because of a new genre of students with learning needs vastly different from their predecessors. In addition, it is increasingly recognized that effective use of technology in higher education is essential to providing high-quality education and preparing students for the challenges of the 21stcentury as underscored by (Masud et al, 2012).

\section{Marketing}

Micro, small and medium-sized enterprises (MSMEs) in Rwanda are eager to take advantage of digital markets where virtually no physical borders will inhibit them. Together with the Ministry of Trade and Industry and in partnership with GIZ, the German development agency, and DHL, a global logistics company, ITC is supporting these MSMEs sell online by developing the capabilities of the entrepreneurs and by providing innovative solutions to barriers that can impede the development of e-commerce including high logistic costs. As more consumers globally switch to buying online, it will be critical for Rwandan companies to improve their online capabilities to be able to rapidly respond to changing consumer preferences.

Launched in 2017, the starting point of the Enabling the Future of e-commerce in Rwanda project, involved extensive market research to understand consumer behavior and assess the potential for e-commerce in Kigali, Rwanda. To design a comprehensive e-commerce marketing strategy, ITC performed 800 interviews with local consumers to understand where and how the local population expects to buy goods online. The interviews were highly revealing, indicating that for many local producers the most relevant opportunities for selling online would be through international marketplaces.

\section{Cloud Computing in Tanzania}

Cloud computing is now a topic of significant impact and, while it may represent an evolution in technology terms, the truth behind this approach is that it has changed how both academia and industry are thinking and acting. If cloud computing is of today's key technologies for the modernization and realization of the public sector as advocated by many, the belief is that cloud is part of the new trend of technology that is set to take the computing experience to another level With huge finances needed in higher education globally and the growing demand for IT services, universities in Africa are facing challenges in providing essential Information and Communication Technology (ICT) support for educational, research and developmental activities. Although universities have been using "cloud-based" applications for years (e.g., email), the cloud computing fashion is quickly evolving into a premium model for data storage and exchange. According to Gartner a technology research company, more than 50 percent of Global 1000 companies are predicted to store confidential data in the public cloud by the end of 2016. The cloud is proving itself as being (a) tech-oriented that is here to stay. 


\section{Agriculture}

Youthful dairy agropreneurs need access to information on livestock diseases, nutrition, treatment, and control of diseases, breeding techniques, markets for their products, input markets, and financial and credit services [10]. These dairy agropreneurs may access the information through radio, television (TV), and mobile phones in various forms such as agricultural programs, advertisements, feature stories, agricultural subscription and free SMS services, mobile applications, e-commerce platforms for inputs and produce and videos [11] Some examples of recent ICT-based initiatives that target Tanzanian dairy farmers include Shamba-shape up that airs on radio and TV and through their website iShamba, iCow that disseminates information through SMSs and through their mobile application and the African Dairy Genetic Gains (ADGG) program that records and disseminates on-farm productivity and genetic information through SMS service through a partnership with iCow [12].

\section{Banking}

Cloud computing has become an essential unit of computer technology. Cloud computing plays a very big role in business model innovation which attracts many industries to participate especially the banking sector. For banks in Tanzania, cloud computing solutions have simplified the maintenance and implementation of finance and information systems. [15]

\section{Education}

Tanzania has an average population of 40 million inhabitants and occupies 945,087 (sq km) 1 . The United Republic of Tanzania is a result of the political union between mainland Tanganyika and the offshore islands of Zanzibar and Pemba. Zanzibar has its government and its own Ministry of Education. Administratively, the country is divided into 25 regions with 126 districts in all2. Dodoma is the official capital and home to Tanzanian Parliament while the government ministries and major institutions and diplomatic missions are in Dar es Salaam. Swahili is the official language with English being used as the official primary language of commerce administration and higher education. The basic issues in development are elaborated in Vision 2025 with three principal objectives which are: (1) achieving quality and good life for all, (2) good governance, and the rule of law and, (3) building a strong and resilient economy that can effectively withstand global competition.

Education has been noted in Vision 2025 as a strategic change agent for the transformation and creation of an educated nation. ICT is being recognized as a major driving force for the realization of Vision 2025. It has been noted that the task demands adequate investments to improve the quality of science-based education and the creation of a knowledge-based society. The adoption of cloud computing to embrace education in Tanzania is growing very fast, more and more institutions are migrating their computing services into the cloud. This is further facilitated by the existence of cloud service providers that provide several cloud services for free or at a discount rate to educational institutions.

Cloud computing services provide institutions access to ICT software platforms hosted in their clouds. However, the cost of acquiring managing, and maintaining ICT infrastructure has been a major factor that hinders countries like Tanzania. The cost reduction has been demonstrated by Florida Atlantic University which reduced IT costs by at least U.S. $\$ 600,000$ by migrating Blackboard LMS into the cloud [13]. Likewise, Wake Community College reduced by nearly 50 percent of Total Cost of Ownership (TCO) through migrating traditional ICT infrastructure into the cloud [14]. Similar benefits can be reaped if cloud computing is adopted in BL implementation in Tanzania. 


\section{Marketing}

In the last years, network marketing companies in Tanzania also identified as multi-level marketing, have flooded the East African nation. This is because it has seen the fastest adoption into the mainstream than any other technology in the domain. This adoption has been fueled by mainly the ever-increasing number of smartphones and mobile devices that can access the internet. Cloud computing is not just for organizations and businesses; it is useful for the average person as well. [16].

\subsection{Cloud Computing in Somalia}

Somalia boasts of a population of 15.44 million people according to the population census taken in 2019. Somalia is estimated to have over six million mobile phone users (of a population of about 15million) but lags behind most African countries in terms of international capacity, national connectivity, and Internet take-up. Mobile money has also proved highly popular, with some $72 \%$ of Somalis over the age of 16 using it, and the total value of transactions taking place in it amounting to about US $\$ 2.7$ billion a month. [17]

\section{Agriculture}

This seemingly is the most important sector in an economy, with livestock raising surpassing crop growing fourfold in value and earning about three-fifths of Somalia's foreign exchange. Livestock alone contributes about $40 \%$ to GDP and more than $50 \%$ of export earnings. Cloud computing has been introduced by Ari. Farm, a new Agri-tech app, is helping to bring nomadic Somali livestock farmers into the digital economy. The idea was inspired by a relatively new concept called "crowd-farming," an agricultural adaptation of crowdfunding, which connects farmers with investors through a digital platform. As ICT development and access to mobile internet in developing countries are crucial to achieving the United Nations' Sustainable Development Goals (SDGs) and improving people's lives, Ari farm is one of the many success stories of how rural farmers are benefiting from new applications of mobile technologies. [18]

\section{Banking}

Somalia's banking sector still faces challenges because Somalia has not had an effective central government since the breakout of a civil war in 1991. It is still yet to see a breakthrough with the ability to run software programs without installing them on our computers; it enables us to store and access our multimedia content via the internet, it enables us to develop and test programs without necessarily having servers, and so on. [19]

\section{Education}

[20]. Somali higher education institutions have not fully benefitted from the technology revolution because of the expensive upfront costs of buying hardware and software and managing it on-premise. But more importantly, the lack of an IT skilled workforce prevented the development of supporting ecosystems of service providers, like those available in the industrialized world.

\section{Marketing}

Somalia has been increasing in cloud computing due to the recent changes in information technology but the impact of cloud computing in their marketing system is still yet to have an impact on the marketing firms in Somalia. 


\subsection{Cloud Computing in Ethiopia}

Cloud computing becomes an appealing alternative where organizations are confronted with the need for high processing and extensive storage capabilities, data backup and recovery, IT resource scalability, and high availability at the lowest possible cost. Successful adoption of this technology is the key to enabling the realization of benefits. However, the nature of cloud computing poses adoption challenges to organizations [21].

\section{Agriculture}

Agriculture is a major income source in Ethiopia, and the country's economy is highly dependent on it. It covers half of the country's total GDP, and more than $80 \%$ of the Country's population depends on it. Ethiopia's current agricultural sector has many redundancies, limited-service deliveries, has no advantages of cost from the technology's point of view, even from the farming community. Agriculture in Ethiopia has been suffering from various external and internal issues. It has been inactive due to poor performances as a result of factors such as Low resource utilization, outdated farming techniques, over-dependence on fertilizers, Underutilized methods for soil and water conservation, inappropriate farming policy, problematic land tenure policy, ecological degradation of potentially arable lands, increase in unemployment rate due to increase in the population. Farmers in rural areas depend on climate, traditional methods for cultivation, low use of modern agriculture equipment, machinery, agriculture planting and breeding technology, weather observation, and forecasting, and prominent marketplaces in the country are not easily accessible [23].

\section{Banking}

Cloud services are increasing throughout the banking sector in Ethiopia. Promises of low cost, data availability, and operational and infrastructural efficiency have drawn the banking Sector's attention. Banks seek ways to effectively store and retrieve their data to ensure their success while protecting privacy, integrity, and sharing without compromising security. However, the adoption of cloud-based computing in this sector remains problematic in Ethiopia. One example is the challenges facing the Ethiopian banking sector in using data as a service. Interviews were conducted, and results showed that banks practice data as a service for providing their business with the user using the file transfer protocol. The absence of proper data architecture and management is a significant challenge that prevents banks from using data as a service [22].

\section{Education}

The use of technology to supply educational resources in this century is considered normal, but it is regarded as a luxury in developing countries such as Ethiopia. Ethiopia is currently suffering from budgetary restrictions on education. There are now 31 public universities and many private colleges. The government invests millions of dollars per year in supporting education in higher education institutions through technology. Given the challenging economic climate, it is unable to meet the technological infrastructure needs of all universities.

Ethiopia's education sector has traditionally been cautious about embracing new technology due to factors such as cost and risk due to its struggling technology. But cloud computing could be a very acceptable solution for the education sector, helping them adopt changing technologies without the burden of high costs and complexity. Due to the possible problems cloud computing could provide solutions for, education institutions in Ethiopia are beginning to adopt cloud computing, leading to a significant decreasing expense due to the implementation of the cloud services. 


\section{Marketing}

There is little cloud computing experience in Ethiopia since most of this study took place at its very early deployment stage.

\section{RESULTS}

Following a review of how cloud computing affects different industries in the countries mentioned above, the analysis below provides a summary of its impact:

Table 1: Cloud computing in Kenya

$\begin{array}{lllll}\text { Factors } & \text { KBC group } & \begin{array}{l}\text { Rea vipingo sisal } \\ \text { Estate }\end{array} & \begin{array}{l}\text { Pacific Insurance } \\ \text { Brokers }\end{array} & \begin{array}{l}\text { Datum } \\ \text { intel }\end{array} \\ \text { Banking } & \mathrm{x} & \mathrm{x} & & \mathrm{x} \\ \text { Agriculture } & \mathrm{x} & \mathrm{x} & \mathrm{x} & \mathrm{x} \\ \text { Education } & \mathrm{x} & \mathrm{x} & \mathrm{x} & \mathrm{x} \\ \text { Marketing } & \mathrm{x} & \mathrm{x} & \end{array}$

In table 1, there is an adoption of cloud computing in most of the sectors considered concerning different companies in Kenya. Only a few have no cloud computing in these companies. Banking having a 75\% adoption, Agriculture having a 50\%, Education having a 75\%, and Marketing having the highest percentage of 100 in these sectors for their companies.

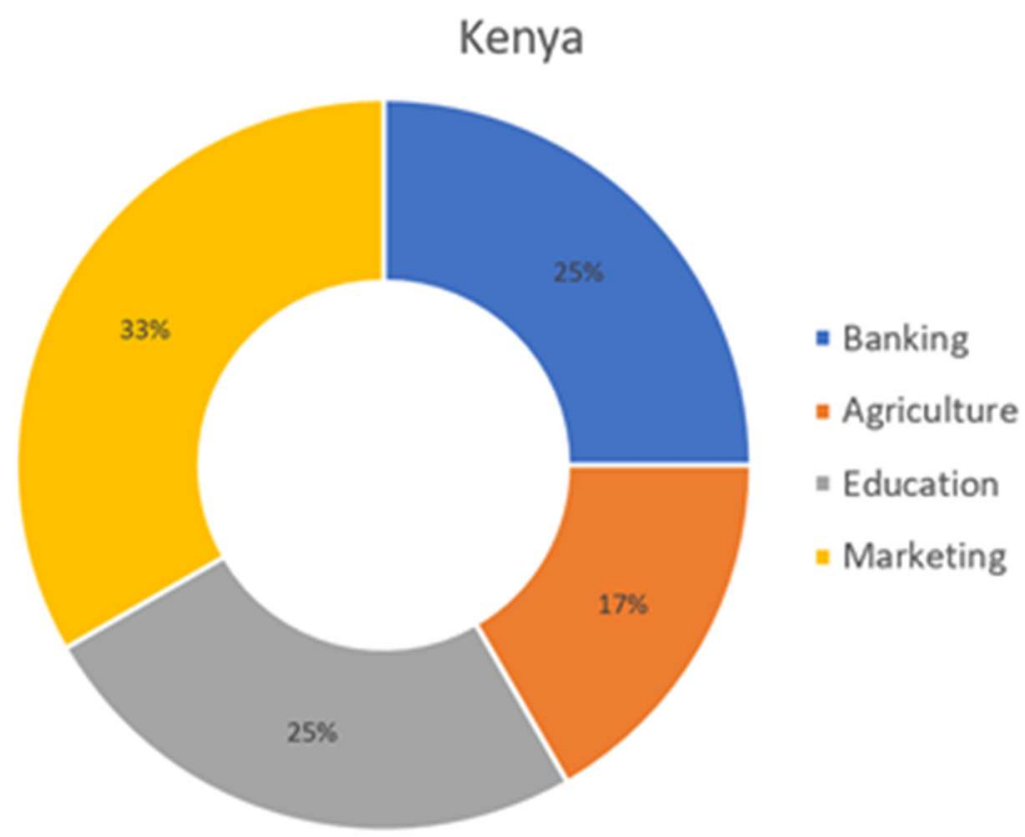

Figure 1 is the representation of table 1 on a pie Chart.

On this chart, Marketing has a share of $33 \%$, Banking a share of $25 \%$, Education a share of $25 \%$ and leaving Agriculture with a share of $17 \%$. 
Table 2: Cloud Computing in Rwanda

$\begin{array}{lllll}\text { Factors } & \text { Eco bank Rwanda } & \text { Terracom } & \text { Kigali Farms } & \text { Rwanda Air } \\ \text { Agriculture } & \mathrm{x} & & \mathrm{x} & \\ \text { Banking } & \mathrm{x} & \mathrm{x} & \mathrm{x} & \mathrm{x} \\ \text { Education } & \mathrm{x} & \mathrm{x} & & \mathrm{x} \\ \text { Marketing } & \mathrm{x} & \mathrm{x} & \mathrm{x} & \mathrm{x}\end{array}$

Table 2 contains the quantitative analysis of this research concerning Rwanda. Here, once again marketing sector has the highest percentage which is $100 \%$, education has $50 \%$, banking has $100 \%$ alongside marketing, leaving agriculture with 50\%.

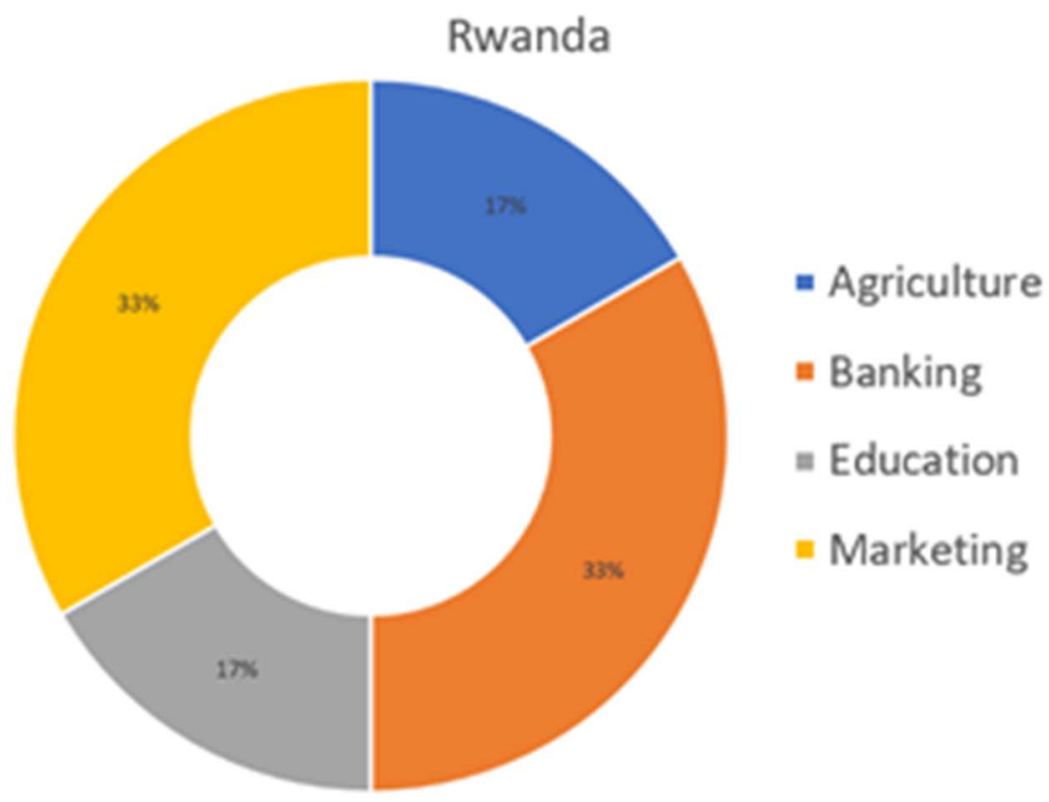

Figure 2 represents the details in table 2.

Both Marketing and banking have a share of 33\% and both agriculture and education have the share of $17 \%$.

Table 3: Cloud Computing in Tanzania

$\begin{array}{lllll}\text { Factors } & \text { Cool print } & \text { Bumaco Insurance } & \text { AgriTech } & \text { Eco bank } \\ & \text { Arusha } & \text { Company } & \text { Company } & \text { Tanzania } \\ \text { Agriculture } & \mathrm{x} & \mathrm{x} & \mathrm{x} & \mathrm{x} \\ \text { Banking } & \mathrm{x} & \mathrm{x} & \mathrm{x} & \mathrm{x} \\ \text { Education } & & \mathrm{x} & \mathrm{x} & \mathrm{x} \\ \text { Marketing } & \mathrm{x} & \mathrm{x} & \mathrm{x} & \mathrm{x}\end{array}$

In table 3, the research was concerned with Tanzania. From this table, Tanzania has the highest level of Cloud computing Adoption in East Africa. This is not far-fetched because East Africa has one of the fastest-growing Technological countries in Africa. All sectors i.e.: Agriculture, Banking, Marketing all have the adoption of $100 \%$. But Education has the adoption of $75 \%$. 


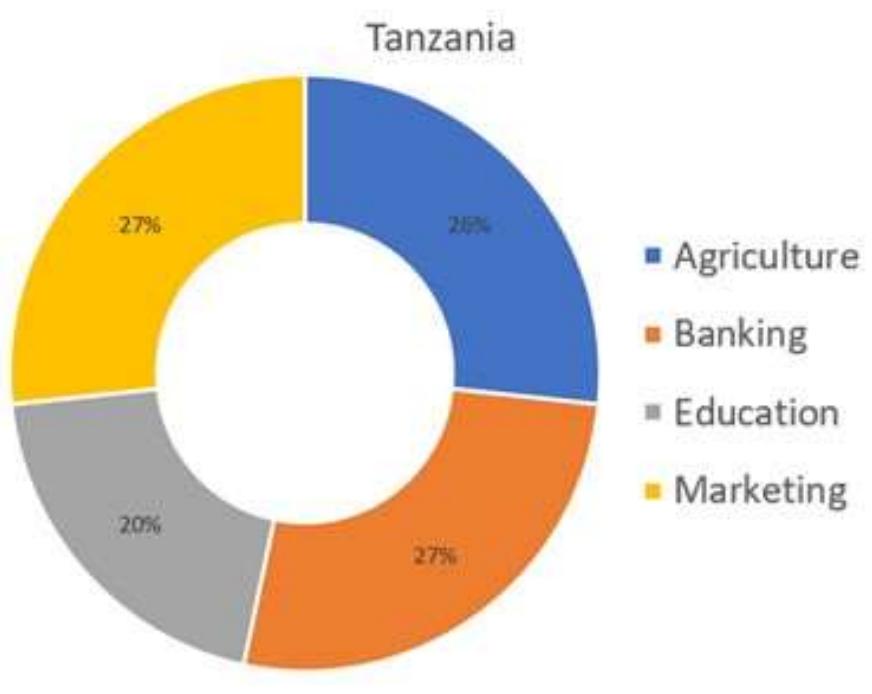

Figure 3 is a representation of the data in table 3.

Banking and marketing have a percentage of $27 \%$. Education has $20 \%$ and agriculture has $26 \%$. Table 4: Cloud computing in Somalia

$\begin{array}{lllll}\text { Factors } & \text { Amal Bank } & \text { Takaful Insurance of } & \text { SEO } & \text { Bile General } \\ & & \text { Africa } & \text { Brand } & \text { Trading co } \\ \text { Agriculture } & \mathrm{x} & \mathrm{x} & \mathrm{x} & \mathrm{x} \\ \text { Marketing } & \mathrm{x} & \mathrm{x} & \mathrm{x} & \mathrm{x} \\ \text { Education } & \mathrm{x} & & \mathrm{x} & \mathrm{x} \\ \text { Banking } & \mathrm{x} & \mathrm{x} & & \mathrm{x}\end{array}$

The table above shows Cloud Computing in Somalia. Agriculture has a 100\% in this analysis based on the companies analyzed. Marketing also has 100\%, Education has 50\% and Banking $100 \%$.

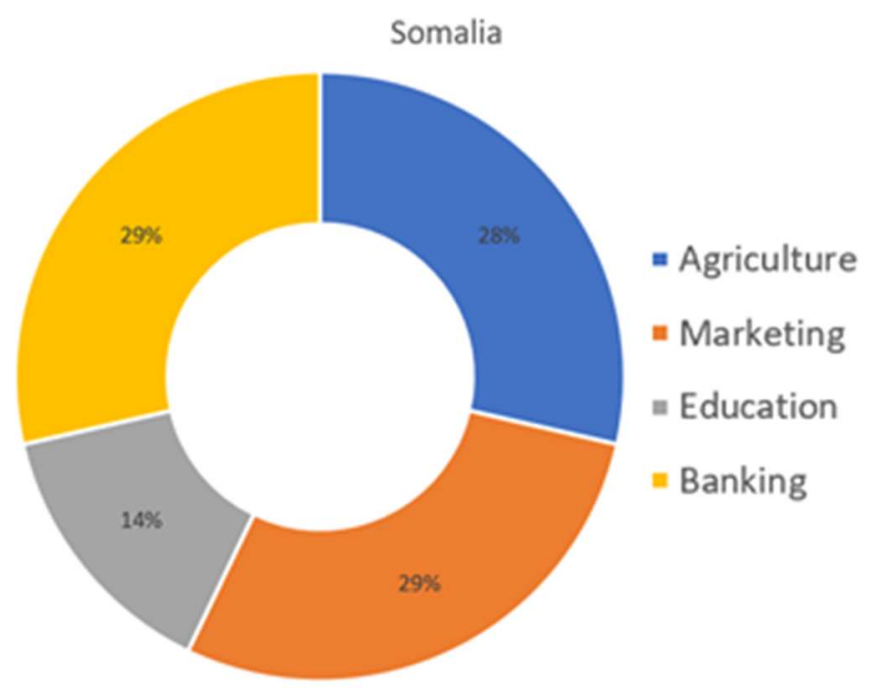

Figure 4 has an analysis of Table 4 which is Somalia. 
Cloud computing has the least adoption in the education sector which is $14 \%$, banking has a $29 \%$, agriculture has a $28 \%$, and marketing a $29 \%$.

$\begin{array}{lllll}\begin{array}{llll}\text { Table 5: Cloud Computing in Ethiopia } \\ \text { Factor }\end{array} & \text { National Bank of } & \text { Nile Insurance } & \text { Nutriyen } & \text { Ethiopian } \\ & \text { Ethiopia } & \text { Company } & & \text { Airline } \\ \text { Agriculture } & \mathrm{x} & \mathrm{x} & \mathrm{x} & \\ \text { Banking } & \mathrm{x} & & & \mathrm{x} \\ \text { Marketing } & \mathrm{x} & \mathrm{x} & \mathrm{x} & \\ \text { Education } & \mathrm{x} & \mathrm{x} & \mathrm{x} & \mathrm{x}\end{array}$

In Ethiopia, the percentage of Education is 100\%. The percentage of Marketing and Agriculture is $75 \%$ respectively. And the analysis shows that Banking has a share of $50 \%$. From this analysis, there is cloud computing Adoption in sectors like Education, marketing, and agriculture more than that of Banking.

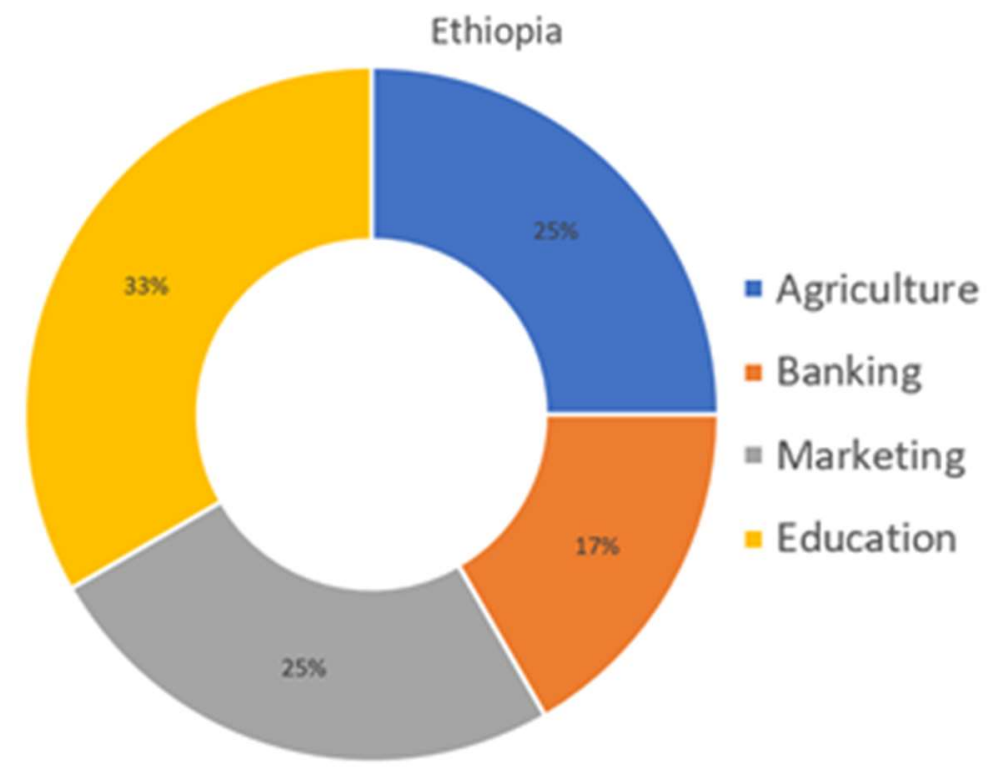

Figure 5 describes the Cloud computing adoption in Ethiopia. T

The sector with the highest percentage and adoption is education. The one with the least adoption percentage is banking, throwing agriculture and marketing in the middle at $25 \%$ each. 
Table 6: Overall Cloud Computing Adoption in East Africa.

\begin{tabular}{|c|c|c|c|c|c|}
\hline Country/Heading & Factors & Banking & Agriculture & Education & Marketing \\
\hline \multirow{4}{*}{ Kenya } & KBC group & $\mathrm{x}$ & $x$ & $x$ & $x$ \\
\hline & $\begin{array}{l}\text { Rea vipingo sisal } \\
\text { Estate }\end{array}$ & $\mathrm{x}$ & $x$ & & $x$ \\
\hline & $\begin{array}{l}\text { Pacific Insurance } \\
\text { Brokers }\end{array}$ & & & $\mathrm{x}$ & $x$ \\
\hline & Datum intel & $\mathrm{x}$ & & $x$ & $x$ \\
\hline \multirow{4}{*}{ Rwanda } & Eco bank Rwanda & $\mathrm{x}$ & $x$ & $x$ & $x$ \\
\hline & Terracom & $\mathrm{x}$ & & $x$ & $x$ \\
\hline & Kigali Farms & $x$ & $x$ & & $x$ \\
\hline & Rwanda Air & $\mathrm{x}$ & & & $x$ \\
\hline \multirow{4}{*}{ Tanzania } & Cool print Arusha & $x$ & $x$ & & $x$ \\
\hline & $\begin{array}{l}\text { Bumaco Insurance } \\
\text { Company }\end{array}$ & $\mathrm{x}$ & $\mathrm{x}$ & $\mathrm{x}$ & $\mathrm{x}$ \\
\hline & Agri Tech Company & $\mathrm{x}$ & $x$ & $x$ & $x$ \\
\hline & Eco bank Tanzania & $\mathrm{x}$ & $x$ & $x$ & $x$ \\
\hline \multirow{4}{*}{ Somalia } & Amal Bank & $\mathrm{x}$ & $x$ & $x$ & $x$ \\
\hline & $\begin{array}{l}\text { Takaful Insurance of } \\
\text { Africa }\end{array}$ & $\mathrm{x}$ & $x$ & $x$ & \\
\hline & SEO Brand & $\mathrm{x}$ & $x$ & $x$ & \\
\hline & $\begin{array}{l}\text { Bile General Trading } \\
\text { co }\end{array}$ & $\mathrm{x}$ & $x$ & $x$ & $x$ \\
\hline \multirow{4}{*}{ Ethiopia } & $\begin{array}{l}\text { National Bank of } \\
\text { Ethiopia }\end{array}$ & $\mathrm{x}$ & $x$ & $x$ & $\mathrm{x}$ \\
\hline & $\begin{array}{l}\text { Nile Insurance } \\
\text { Company }\end{array}$ & & $x$ & $x$ & $x$ \\
\hline & Nutriyen & & $x$ & $x$ & $x$ \\
\hline & Ethiopian Airline & $x$ & & $x$ & \\
\hline Sector total & & 17 & 15 & 16 & 17 \\
\hline
\end{tabular}


Table 6 comprises all the data in the tables above. The tallies of all the other tables from the different countries. The adoption in some countries and companies in these countries is high and impressive. On a scale of 20, the banking and marketing sectors have the highest score of 17 in terms of the adoption of cloud computing. The agricultural sector and education sector score 15 and 16 respectively. We take a scale from 1 to 4; in the banking sector, Kenya scores 3 , Rwanda has a score of 4, Somalia scores 4, Ethiopia scores 2.

This indicates that Ethiopia has the least adoption of cloud computing in East Africa according to our case study. In the agricultural sector, Kenya has a score of 2, Rwanda scores 2, Tanzania scores 4, Somalia scores 4, Ethiopia has a score of 3. This shows that Rwanda and Kenya have the least adoption of cloud computing in the agricultural sector from this case study. In the Education sector, Kenya has a score of 3, Rwanda scores 2, Tanzania scores 3, Somalia scores 4, Ethiopia has a score of 4. this shows that Rwanda has the lowest adoption of cloud computing in the education sector from this case study.

In the Marketing sector, Kenya has a score of 4, Rwanda scores 4, Tanzania scores 4, Somalia scores 2, Ethiopia has a score of 3 . This shows that in years to come, Cloud Computing would be adopted in even the underdeveloped areas and regions of East Africa. Although cloud computing services for records management offer significant benefits to Africa, the continent is not yet ready to fully adopt and benefit from such technologies. Cloud-based records management services are Africa's Achilles heel. Specific data center projects are either operational or in the process of being established in Tanzania and Rwanda.

In Benin and Burundi, plans are being developed to implement cloud computing. The initiatives reported for the other countries surveyed are, though interesting, wider actions or programs that are not specific to cloud computing (regulatory frameworks for electronic transactions, outsourcing of business processes, technology parks). On the regulatory front, it's worth noting that the majority of the countries polled lack data.

\subsection{Analysis of Overall Representation of Cloud Computing in East Africa}

From figure 6 below there is an even adoption of Cloud computing in East Africa. A suitable model to be used when implementing Cloud Computing Technologies should be stressed, and if possible, a model that is in line with the conditions that exist in MHTI in Kenya should be developed for other countries to enhance cloud computing. Providers of cloud technologies and services in Kenya will be well guided to build services that are well suited for MHTI in Kenya with the help of an appropriate model.

To date, the experience of East African countries indicates that cloud computing technology is used at various levels depending on the institutions involved. While a given administration may be just getting ready to implement this new technology, $50 \%$ of the country's ICT operators may have already started to implement or are already using it. 


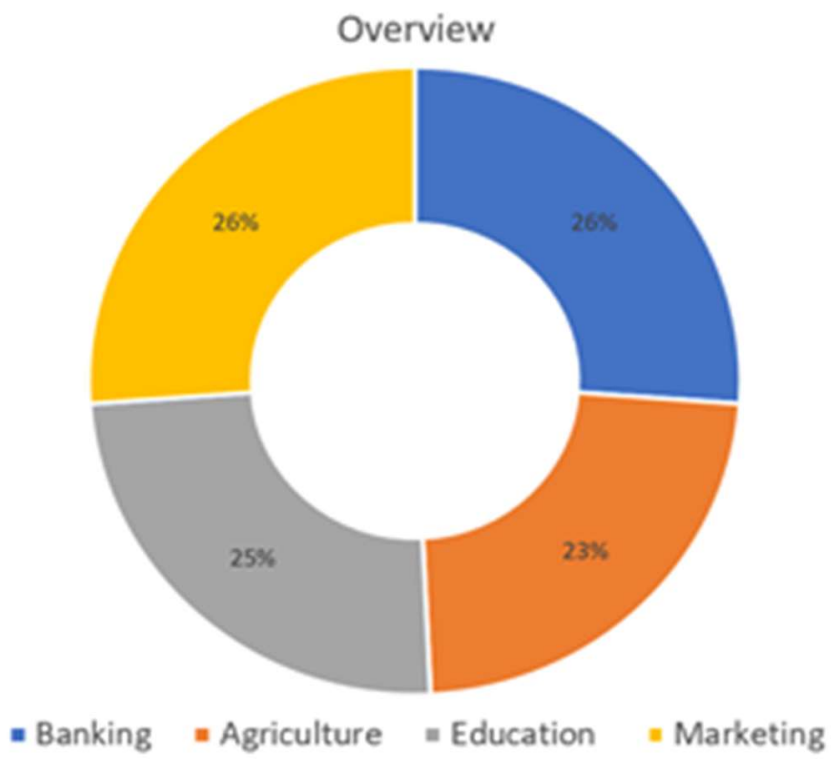

Figure 6 represents the overview of the analysis in the four sectors of our case study These sectors include includes banking, agriculture, education, marketing. In the marketing sector, Kenya has a total adoption of $8.58 \%$, Somalia has a total adoption of $7.54 \%$, Ethiopia has a total adoption of $6.50 \%$, Rwanda has a total adoption of $6.58 \%$, and Tanzania has a total adoption of $7.02 \%$ making up a total of $26 \%$.

In the banking sector, Kenya has a total adoption of $8.07 \%$, Somalia has a total adoption of $6.32 \%$, Ethiopia has a total adoption of $5.95 \%$, Rwanda has a total adoption of $3.34 \%$, and Tanzania has a total adoption of $4.23 \%$ making up a total of $26 \%$.

In the agriculture sector, Kenya has a total adoption of $6.23 \%$, Somalia has a total adoption of $7.66 \%$, Ethiopia has a total adoption of $7.60 \%$, Rwanda has a total adoption of $5.54 \%$, and Tanzania has a total adoption of $4.37 \%$ making up a total of $23 \%$.

In the education sector, Kenya has a total adoption of 5.67\%, Somalia has a total adoption of $6.24 \%$, Ethiopia has a total adoption of $3.60 \%$, Rwanda has a total adoption of $5.31 \%$, and Tanzania has a total adoption of $4.89 \%$ making up a total of $23 \%$. From the analysis of figure 6 , it is evident that although there is slow progress in the adoption of cloud computing in some sectors, cloud computing in East Africa is expected to skyrocket significantly over the next 20 years.

4.2 Sustainable Development Goal \# 1 Poverty

Considering no poverty SDG no.1 as an SDG used for the analysis of cloud computing adoption in east Africa. The following table is used: 
Table 7: East Africa and the SDGs

$\begin{array}{ll}\text { Kenya } & \text { Rwanda } \\ \text { The adoption } & \text { There is an } \\ \text { of cloud } & \text { information and } \\ \text { computing } & \text { communication } \\ \text { requires a } & \text { technology for } \\ \text { very minimal } & \text { development } \\ \text { upfront } & \text { (ICT4D) strategic } \\ \text { investment. } & \text { action plan for } \\ & \text { implementing } \\ & \text { existing national } \\ & \text { information } \\ & \text { technology (IT) } \\ & \text { policy that seeks } \\ & \text { to make IT a } \\ & \text { driver for } \\ & \text { sustainable } \\ & \text { development. }\end{array}$

Public cloud
computing in
Kenya needs
no capital
expenditure
because no
hardware,
software, or
network
devices are
purchased by
the clients.

With cloud computing, organizations, institutions, and companies in Rwanda no longer need to invest heavily in IT resources, which are of necessity limited and require burdensome and costly internal management, instead, there is the option to migrate to a cloud model enabling them to purchase or lease resources online.

\begin{tabular}{|c|c|c|}
\hline Tanzania & Somalia & Ethiopia \\
\hline $\begin{array}{l}\text { Cloud computing } \\
\text { gives small and } \\
\text { medium firms the } \\
\text { ability to } \\
\text { overcome some } \\
\text { of the common } \\
\text { challenges that } \\
\text { affect SMEs } \\
\text { negatively more } \\
\text { than large } \\
\text { enterprises such } \\
\text { as the financial IT } \\
\text { utilizing and } \\
\text { operational costs } \\
\text { by hiring the } \\
\text { required } \\
\text { resources and } \\
\text { paying for the } \\
\text { used services only } \\
\text { as SMEs usually } \\
\text { rely on limited } \\
\text { budgets } \\
\text { comparing to } \\
\text { large firms }\end{array}$ & $\begin{array}{l}\text { The migration } \\
\text { to cloud } \\
\text { computing } \\
\text { often entails } \\
\text { additional, } \\
\text { unexpected } \\
\text { costs, and } \\
\text { although those } \\
\text { costs are } \\
\text { affordable and } \\
\text { do not } \\
\text { jeopardize the } \\
\text { positive result } \\
\text { of adopting } \\
\text { cloud, some } \\
\text { operations can } \\
\text { turn out to be } \\
\text { very costly, } \\
\text { particularly if } \\
\text { they are not } \\
\text { prepared on } \\
\text { time. }\end{array}$ & $\begin{array}{l}\text { Despite the } \\
\text { development of } \\
\text { international } \\
\text { data } \\
\text { transmission } \\
\text { links between } \\
\text { Africa and the } \\
\text { rest of the } \\
\text { world, the costs } \\
\text { associated with } \\
\text { the bandwidth } \\
\text { necessary for } \\
\text { transferring } \\
\text { "African data" } \\
\text { to and from } \\
\text { cloud } \\
\text { computing } \\
\text { resources } \\
\text { located outside } \\
\text { Ethiopia } \\
\text { (whether for } \\
\text { storage or data } \\
\text { consultation } \\
\text { purposes) are } \\
\text { so high }\end{array}$ \\
\hline
\end{tabular}

These features in cloud computing such as scalability, accessing the global market and capital, and increasing SMEs global collaborations allows SMEs to focus more on developing and growing their business than spending time and money in managing and operating the IT resources
The frequent movement of data between company and cloud can also rack up the costs, particularly in terms of bandwidth consumption where transfer times are lengthy.
It is more advantageous to construct data storage centers in Ethiopia than to pay for accessing centers located tens of thousands of kilometers away from the continent. 


\begin{tabular}{|c|c|c|c|c|}
\hline Kenya & Rwanda & Tanzania & Somalia & Ethiopia \\
\hline $\begin{array}{l}\text { Cloud } \\
\text { computing } \\
\text { resources can } \\
\text { be rapidly } \\
\text { allocated and } \\
\text { de-allocated } \\
\text { on demand } \\
\text { thus lowering } \\
\text { operating } \\
\text { costs. }\end{array}$ & $\begin{array}{l}\text { The availability of } \\
\text { online services } \\
\text { also frees users } \\
\text { from the need to } \\
\text { acquire hardware } \\
\text { by paying instead } \\
\text { for the resources } \\
\text { used. This model } \\
\text { has already been } \\
\text { adopted by many } \\
\text { companies, } \\
\text { particularly small } \\
\text { and medium- } \\
\text { sized firms and } \\
\text { very small firms in } \\
\text { Rwanda. }\end{array}$ & $\begin{array}{l}\text { By gaining } \\
\text { support from the } \\
\text { largest ICT } \\
\text { companies } \\
\text { such as Google, } \\
\text { Amazon, and } \\
\text { Microsoft, cloud } \\
\text { computing is } \\
\text { being widely } \\
\text { embraced by } \\
\text { many } \\
\text { organizations }\end{array}$ & $\begin{array}{l}\text { A report } \\
\text { produced by } \\
\text { the Hedera } \\
\text { Technology } \\
\text { consultancy } \\
\text { firm on the } \\
\text { Internet in } \\
\text { Somalia points } \\
\text { to } \\
\text { shortcomings } \\
\text { associated with } \\
\text { poor quality of } \\
\text { service due to } \\
\text { under- } \\
\text { investment in } \\
\text { communication } \\
\text { networks, } \\
\text { making it } \\
\text { difficult to } \\
\text { abide by } \\
\text { clauses } \\
\text { guaranteeing } \\
\text { quality levels } \\
\text { and access } \\
\text { speeds for } \\
\text { cloud } \\
\text { computing } \\
\text { services }\end{array}$ & $\begin{array}{l}\text { The Balancing } \\
\text { Act report } \\
\text { predicts that } \\
\text { key Ethiopian } \\
\text { operators will } \\
\text { soon be } \\
\text { addressing the } \\
\text { implementation } \\
\text { of new services } \\
\text { based solely on } \\
\text { the cloud. }\end{array}$ \\
\hline $\begin{array}{l}\text { Cloud } \\
\text { computing } \\
\text { reduces } \\
\text { business risks } \\
\text { and } \\
\text { maintenance } \\
\text { expenses as } \\
\text { these tasks } \\
\text { are passed on } \\
\text { to the cloud } \\
\text { service } \\
\text { provider. }\end{array}$ & $\begin{array}{l}\text { In an economic } \\
\text { context where } \\
\text { companies are } \\
\text { seeking to make } \\
\text { the most of their } \\
\text { investments and } \\
\text { minimize } \\
\text { operating costs, } \\
\text { cloud computing } \\
\text { is seen as the } \\
\text { solution for } \\
\text { tomorrow. }\end{array}$ & $\begin{array}{l}\text { In education, the } \\
\text { adoption of cloud } \\
\text { computing will } \\
\text { enable schools to } \\
\text { implement } \\
\text { eLearning } \\
\text { systems without } \\
\text { procuring and } \\
\text { hosting ICT } \\
\text { infrastructure in } \\
\text { their premises }\end{array}$ & $\begin{array}{l}\text { It was } \\
\text { recommended } \\
\text { to encourage } \\
\text { adoption of the } \\
\text { cloud } \\
\text { computing and } \\
\text { the } \\
\text { construction of } \\
\text { data centers in } \\
\text { Somalia to } \\
\text { reduce service } \\
\text { access costs. }\end{array}$ & $\begin{array}{l}\text { The migration } \\
\text { to cloud } \\
\text { computing } \\
\text { often entails } \\
\text { additional, } \\
\text { unexpected } \\
\text { costs, and } \\
\text { although those } \\
\text { costs are } \\
\text { affordable and } \\
\text { do not } \\
\text { jeopardize the } \\
\text { positive result }\end{array}$ \\
\hline
\end{tabular}




\begin{tabular}{|c|c|c|c|c|}
\hline Kenya & Rwanda & Tanzania & Somalia & Ethiopia \\
\hline $\begin{array}{l}\text { The scalability } \\
\text { of cloud } \\
\text { computing } \\
\text { allows } \\
\text { organizations } \\
\text { to demand } \\
\text { computing } \\
\text { resources and } \\
\text { services on a } \\
\text { need basis. }\end{array}$ & $\begin{array}{l}\text { Cloud computing } \\
\text { works via the } \\
\text { Web, with access } \\
\text { to services using } \\
\text { a simple browser } \\
\text { and, increasingly, } \\
\text { with free } \\
\text { operating } \\
\text { systems. }\end{array}$ & $\begin{array}{l}\text { Organizations can } \\
\text { save substantial } \\
\text { capital costs for } \\
\text { purchasing } \\
\text { hardware and } \\
\text { software, } \\
\text { administration } \\
\text { and } \\
\text { operational costs } \\
\text { associated with } \\
\text { hardware } \\
\text { maintenance, } \\
\text { software } \\
\text { licensing, electric } \\
\text { power, cooling } \\
\text { System and } \\
\text { wages for ICT } \\
\text { personnel. }\end{array}$ & $\begin{array}{l}\text { Increasing the } \\
\text { physical } \\
\text { proximity } \\
\text { between cloud } \\
\text { computing } \\
\text { resources and } \\
\text { end-user will } \\
\text { produce } \\
\text { immediate } \\
\text { savings in } \\
\text { bandwidth } \\
\text { budgets while } \\
\text { accelerating } \\
\text { access to cloud } \\
\text { computing } \\
\text { resources. }\end{array}$ & $\begin{array}{l}\text { It cannot } \\
\text { automatically } \\
\text { be inferred } \\
\text { from this that } \\
\text { all the new } \\
\text { economic } \\
\text { models being } \\
\text { ushered in by } \\
\text { cloud } \\
\text { computing } \\
\text { systematically } \\
\text { guarantee } \\
\text { significant } \\
\text { financial gains, } \\
\text { whether for } \\
\text { cloud providers } \\
\text { or cloud service } \\
\text { users. }\end{array}$ \\
\hline
\end{tabular}

\section{CONCLUSION}

In East Africa, Cloud computing is still an up-and-coming technology that still has not been in full effect in some countries. During the course of the project, we have seen the issues concerning restricted progress in the affected countries, but from the various materials used in the research of the project, we have long concluded that in due time the adoption of cloud computing will be in full effect in the years to come.

Over the years, the adoption of Cloud Computing in East Africa has been positively increasing. Although some countries in this region have very little technology to support Cloud computing, the research conducted makes it possible to believe that there will be a definite increase in the adoption of cloud computing in East Africa even if the growth rate is not estimated or known from this research. 


\section{REFERENCES}

[1] H. G. Marcus and D. A. Low, "Eastern Africa," 21 March 2021. [Online]. Available: https://www.britannica.com/place/eastern-Africa.

[2] K. Muhammed, I. Zaharaddeen, K. Rumana and A. M. Turaki, "Cloud Computing Adoption in Nigeria: Challenges and," International Journal of Scientific and Research Publications, 2015.

[3] I. Sowunmi, "Business Opportunities in Africa and the Future of Cloud Computing," 31 August 2020. [Online]. Available: https://mynewsbite.wordpress.com/2020/08/31/business-opportunities-in-africa-andthe-future-of-cloud-computing-by-patrick-ndegwa/.

[4] National Institute of Standards and Technology, "Final Version of NIST Cloud Computing Definition Published," 8 January 2018. [Online]. Available: https://www.nist.gov/newsevents/news/2011/10/final-version-nist-cloud-computing-definition-published.

[5] W. Voorsluys, J. Broberg and R. Buyya, "Introduction to Cloud Computing," 2011.

[6] A. A. Dahiru, J. M. Bass and I. K. Allison, "Cloud computing adoption in sub-Saharan Africa: An analysis using institutions and capabilities," in International Conference on Information Society, 2014.

[7] A. Luo, "What is content analysis and how can you use it in your research?," 15 February 2021. [Online]. Available: https://www.scribbr.com/methodology/content-analysis/.

[8] B. Chakravorti and R. S. Chaturvedi, "Research: How Technology Could Promote Growth in 6 African Countries," 4 December 2019. [Online]. Available: https://hbr.org/2019/12/research-how-technology-could-promote-growth-in-6-africancountries.

[9] S. Anderson, "The New Nomads and Cloud Computing in Africa," 27 October 2010. [Online]. Available: https://nextbillion.net/the-new-nomads-and-cloud-computing-inafrica/.

[10] Food and Agriculture Organization of the united nations , Youth and agriculture:key challenges and concrete solutions, Published by the Food and Agriculture Organization of the United Nations (FAO), 2014.

[11] w. P. mtega and a. msungu, Using Information and Communication Technologies for Enhancing the Accessibility of Agricultural Information for Improved Agricultural Production in Tanzania, researchgate, 2013.

[12] s. feleke, E. Gathungu, G. Owuor, O. I. Ayuya and F. Yildiz, "Effect of ICT tools attributes in accessing technical, market and financial information among youth dairy agripreneurs in Tanzania," taylor and francis , pp. 1-17, 2020.

[13] j. mtebe and m. kissaka, Deployment and Adoption Strategy of Cloud Computing for Blended Learning in Higher Education Institutions in Sub-Saharan Africa, IGI Global book series, 2015.

[14] J. S. Mtebe, "Exploring the Potential of Clouds to Facilitate the Adoption of Blended," International Journal of Education and Research , 2013.

[15] N. Niazmand, "The impact of Cloud Computing in the," International Journal of Information, Security and System Management, pp. 1-5, 2015. 
[16] GV Sub-Saharan Africa, "network marketing," 28 june 2020. [Online]. Available: https://globalvoices.org/2020/06/28/network-marketing-in-tanzania-turns-billionairedreams-into-nightmares/.

[17] world bank group, Rapid Growth in Mobile Money:Stability or Vulnerability?, Federal Republic of Somalia, 2018.

[18] I. News, "Agritech app brings Somali livestock farmers into the digital economy," 20 april 2017. [Online]. Available: https://news.itu.int/agritech-app-brings-somali-livestockfarmers-into-the-digital-economy/.

[19] OpenCirrus, "Why is cloud computing important?," 14 september 2018. [Online]. Available: https://opencirrus.org/cloud-computing-important/.

[20] D. M. Adam, P. D. E. A. Elmutalib and D. B. Mohamed, "A Quantitative Study of the Factors Affect Cloud Computing Adoption in Higher Education Institutions: A Case Study of Somali Higher Education Institutions," European Journal of Computer Science and Information Technology , 2019.

[21] P. B. Henze, "A History of Ethiopia," springerlink, 2000.

[22] D. H. Tesema, "Cloud computing adoption challenge in case of commercial bank of ethiopia," International Journal of Development Research, 2020.

[23] D. Welteji, A critical review of rural development policy of Ethiopia: access, utilization and coverage, Springer Nature, 2018.

[24] A. Formoso, J. Chavula, A. Phokeer, A. Sathiaseelan and G. Tyson, "Deep Diving into Africa's Inter-Country Latencies," IEEE INFOCOM 2018 - IEEE Conference on Computer Communications, 2018.

[25] R. Fanouab, F. Valerab, P. Francoisc and A. Dhamdhere, "Reshaping the African Internet: From scattered islands to a connected continent," Computer Communications, pp. 25-42, 2017. 